\title{
Assessing Regional Finance Independence in Indonesian Local Governments
}

\author{
Ermawati and Khoirul Aswar
}

\begin{abstract}
This study aims to identify the effects of local tax, tax revenue sharing, special allocation fund, and capital expenditure on the regional finance independence in Indonesia's local governments. This study uses all districts/cities within the Central Java as a sample. The sample identification uses the purposive sampling method. Secondary data used in this study originates from the report of examination of the local government financial report and the summary of examination published per semester by the national audit board of the Republic of Indonesia. A total of 161 samples were retrieved, resulting in a total of 175 samples. The hypothesis testing was done using the multiple linear regression analysis method. The results of this research show that local tax, tax revenue sharing revenue, has a significant relationship on the regional finance independence in Indonesia's local governments. While, allocational fund and capital expenditure does not have a relationship on the regional finance independence in Indonesia's local governments.
\end{abstract}

Keywords - Regional finance independence, local tax, tax revenue sharing, special allocation fund, capital expenditure.

\section{INTRODUCTION}

The image of Regional Finance Independence in autonomy can be known by how much ability the financial resources have to be able to develop their regions (Nggilu et al. 2016). Regional Finance Independence shows the local government ability to financing their own governance activity, development and services to the people who already paid their taxes and retributions as the sources needed by the region. (Halim 2007:232)

The phenomena taken from this study, namely data taken from the National Secretariat of the Indonesian Forum for Budget Transparency (Seknas FITRA) which produced the Local Budget Analysis Report (AAD) from 2014 to 2016 in 70 district/municipalities, in Central Java Province's district/municipalities, there are 9 district where the ratio of Regional Finance Independence is considered very low, ranging from $9 \%-16 \%$ (APBD, 2018). Its seem that the ratio of Regional Finance Independence is occupying the very low category on scale of $0 \%$ to $25 \%$, so the level of Regional Finance Independence is still really depending on transfer funds from the central governance that will be resulting in economic turbulence which will be influencing the local development.

Furthermore, on Capital Expenditures, based on Regulations of the Minister for Home Affairs (Permendagri)

Published on January 8, 2020.

Ermawati, is lecturer at Economics and Business Faculty Universitas Pembangunan Nasional Veteran Jakarta, Indonesia.

(e-mail: gema_upn@yahoo.com)
No. 27 of 2013 concerning Guidelines for the preparation of the 2014 Provincial Governance Budget (APBD), the provisions regarding the amount of Capital Expenditures is set at $30 \%$ of total local expenditures. The large Capital Expenditures from Local Government is expected to give positive impact because it will be increasing new local revenues potential. Based on the analysis of district and municipalities expenditures, the following district and municipalities are with average Capital Expenditure that didn't fit the Regulations of the Minister for Home Affairs (Permendagri) No. 27 of 2013 during 2014 to 2016; Jepara district (12\%), Wonogiri district (13\%), and Surakarta City (14\%). Based on the phenomena above, could be concluded that on district/municipalities in Central Java Province still very dependant on transfer fund that so the Regional Finance Independence ratio is very low, as well as the average level of Capital Expenditures in the district/municipalities of Central Java Province which is still very low thereby reducing Regional Finance Independence.

By the phenomena that has been described previously to strengthen the influence of Regional Finance Independence, writer will conducting another research. Although there were previous research that has been devoted, but they showed inconsistent result. Some research has proven that local taxes on Regional Finance Independence such as Nggilu, et al. (2016), Darmayasa \& Bagiada (2013), Wong (2004), Edogbanya, et al. (2013) and Novalistia (2016) stated that local taxes are affecting Regional Finance Independence. However, those studies are different from Kadafi \& Putra (2013) that stating local taxes have no effect on Regional Finance Independence. The relation between tax revenue sharing and Regional Finance Independence was also examined by researchers. As studies by Darmayasa \& Bagiada (2013) and Novalistia (2016) stated that tax revenue sharing affects Regional Finance Independence. While the result of Kadafi \& Putra's research (2013) was stating that tax revenue sharing had no effect on Regional Finance Independence.

The result of studies by Tjahjono \& Oktavianti (2016) and Nurhasanah \& Maria (2017) stated that Special Allocation Funds (DAK) is affecting Regional Finance Independence. However, those studies are different with the result of Naganathan \& Sivagnanam (2000) and Susanti, et al.'s (2016) studies which stating that Special Allocation Funds (DAK) has no effect on Regional Finance Independence. In the studies that conducted by Imawan \& Wahyudin (2014), Ariani \& Putri (2016) and Ernawati (2017), stated Capital Expenditures are affecting Regional Finance Independence. Nevertheless, the studies are contradicting the study conducted by Darsono (2013) which stated that Capital 
Expenditures have no effects on Regional Finance Independence.

In particular, this paper focuses on the influencing factors which will lead to study in exploring the regional finance independence with a focus on the Indonesian local government. Furthermore, the objective of study is to examine the relationship between Local Tax, Tax revenue sharing-sharing, Special Allocation Fund and Capital Expenditure on Regional Finance Independence.

\section{LITERATURE REVIEW}

\section{A. Agency Theory}

Agency Theory is the relationship between two parties, which are the party that gives the authority called principal and the party that receives the authority called agent. The linkage of agency theory in this study can be seen through the relationship between central government and local government. The relationship between central government and local government is equal to the relationship between principle and agent. According to Halim \& Kusufi (2012:128) that stated "Agency Theory is the theory of principal relations with agent". Another case with Harahap (2012:532) which proclaimed "Agency Theory stated that company is the place for contractual relationship occurred between management, owner, creditor, and government".

\section{B. Regional Finance Independence}

The implementation of local autonomy bring a very big impact on regional management, region has a high financial management authority, with the authority region is also authorized to make policies to create and improve people's welfare. An autonomous region should have financial capability to run the government, an independent region is characterized by a reduction in financial dependence from the center. According to Halim (2007:232), stated that "Regional Finance Independence (fiscal autonomy) shows the ability of local government to finance their own government activities, development, and services to people who already paid their taxes and retributions as the revenue sources needed by the region". Previous study related to Regional Finance Independence conducted by Ernawati (2017) states that "independence ratio illustrates the level of community participation in regional development".

From the description above, we can conclude that Regional Finance Independence shows how big the ability of local financial resources to develop their region. Regions are demanded to furtherly increase their Regional Finance Independence in order to finance various local expenditures, and financial dependence to central governance should also be reduced in line with the increased of local independence.

\section{Hyphotesis DEVElopment AND CONCEPTUAL SCHEME}

Local taxes is an important source of local income to finance local governance and local development to establish wide, real, and responsible local autonomy (Nggilu et al. 2016). Stakeholders theory discuss that all wealth controlled by local government must be used and utilized for the benefit of the people, because people provide resources to government in the form of local taxes, so there's a reciprocal relation between government and people to create balance in the government and the higher local taxes paid by the people it will be increasing local financial independent in that region. (Novalistia, 2016). The previous studies conducted by Darmayasa and Bagiada (2013), Nggilu, et al. (2016), Novalistia (2016), Edogbanya, et al and Wong (2004) examined the effect of local taxes on Regional Finance Independence. The result of previous studies stated that local taxes affecting Regional Finance Independence. Therefore, the hypothesis is formulated as follows:

$\mathrm{H}_{1}$ : Regional Taxes affecting Regional Financial Independence.

Tax Revenue-Sharing for local government is a balanced funds sourced from the National Budget (APBN) which is shared to region based on certain percentage figured by observing the potential of taxes producer region. Agency Theory discussing that central government has the authority to local government, central government allocated funds from taxes revenue-sharing to local government based on certain percentage number but there are often some problem of distribution delays every quarter that makes agency problems arise between central and local government because of causing disruption of the local development planning (Nugraha and Dwirandra, 2016). Previous studies conducted by Darmayasa and Bagiada (2013) and Novalistia (2016), examined the effect of taxes revenue-sharing on Regional Finance Independence. The previous studies result claimed that taxes revenue-sharing affecting Regional Finance Independence. . Therefore, the hypothesis is formulated as follows:

\section{$\mathrm{H}_{2}$ : Tax Revenue Share affects Regional Financial Independence.}

Special Allocation Funds is a form of local revenue sourced from the balance funds allocated to certain regions to help them fund their physical needs of basic facilities and infrastructure which are national priority in education, health, infrastructure, marine and fisheries, agriculture, local government infrastructure, and the environment. Agency theory discuss that government trusts local governments by transferring funds to manage their regions which aims to maximize public services and to provide public welfare (Untung et al. 2017). The previous studies conducted by Tjahjono and Oktavianti (2016), Nurhasanah and Maria (2017), Susanti et al. (2016) and Naganathan and Sivagnanam (2000) examined the effects of special allocation funds on Regional Finance Independence. These previous studies stated that special allocation funds affecting Regional Finance Independence. Therefore, the hypothesis is formulated as follows:

$\mathrm{H}_{3}$ : Special Allocation Funds affecting the Regional Finance Independence

Capital Expenditures are generally allocated to the acquisition of fixed assets that can be used as regional development tools. The development of region infrastructure and facilities will impacting the local economic growth (Imawan and Wahyudin 2014). Stakeholders theory explained how government regulates budget policies that are pro to people, people also wants to know how much the portion of local government revenue 
are allocated for capital expenditures which are closely related with infrastructure and facilities development, so that high capital expenditures will boost regional finance independence (Yumina et al. 2017). Previous studies conducted by Ernawati (2017), Ariani and Putri (2016), and Imawan and Wahyudin (2014) examined the effect of capital expenditures to region finance independence. The result of previous studies stated that capital expenditures affecting region finance independence. So the hypothesis is formulated as follows:

\section{$\mathrm{H}_{4}$ : Capital Expenditures affects Region Finance Independence}

\section{Research Methodology}

Population that will be the object of this research is Local Governments of district/municipalities in Central Java Province in 2012 to 2016 . The sampling in this study are Local Government of district/municipalities in Central Java Province Financial Reports for 2012 to 2016 that had been audited by Indonesia's State Auditor (BPK RI). This study gained sample amount of 35 district/municipalities in Central Java with 175 total sample. Sekaran (2006:124) stated the reasons for using these sampling are because of time factors, cost, and other human resources. This research using purposive sampling method, purposive sampling is purposive sampling is the method which limited to certain types that can provide the desired information or meet several criteria determined by the researcher.

Regional Finance Independent is measured by total Regional Own Source Revenue divided by central or provincial government assistance and loans. Data taken from Inspection Report (LHP) especially in the Budget Realization Report (LRA). The data scale used is the ratio data scale.

Local Taxes is measured by realization of local taxes divided by realization of total local revenue. Data taken from Inspection Report in Budget Realization Report. The data scale used is the ratio data scale.

Furthermore, Taxes Revenue-Sharing can be measured by total Taxes Revenue-Sharing Funds divided by Total Realization of Local Revenue. Data taken from Inspection Report in Budget Realization Report. The data scale used is the ratio data scale.

Special Allocation Funds measured by Total Realization of Special Allocation Funds divided by Total Realization of Local Revenue. Data taken from Inspection Report (LHP) in Budget Realization Report. The data scale used is the ratio data scale.

\section{Results And Discussion}

\section{A. Descriptive Analysis}

Based on the results of descriptive statistics in table 2, this obtained an overview of each variable studied as follows, Regional Financial Independence has an average of 0.158942 , this shows that the average Regional Financial Independence in Regency / City in Central Java in 2012 until 2016 has an instructive relationship patterns ( $0 \%-25 \%)$, which means that the average Regional financial capacity is very low. The Local Tax have an average of 0.037667 when the Tax Sharing has an average of 0.028446 . While the special allocation funds have an average of 0.063948 , then the Capital Expenditures have an average of 0.178047.

\begin{tabular}{cccccc}
\multicolumn{7}{c}{ TABLE I: RESUlts OF DESCRIPTIVE STATISTICS } \\
\hline Variable & N & Min & Max & Mean & \multicolumn{1}{c}{ SD } \\
\hline RFI & 161 &, 613 & 0.5179 &, 158942 &, 06082 \\
LT & 161 &, 0090 &, 2445 &, 037667 &, 0327635 \\
TRS & 161 &, 0093 &, 1272 &, 028446 &, 0165514 \\
SAF & 161 &, 0008 &, 1843 &, 063948 &, 0401724 \\
CE & 161 &, 0495 &, 3603 &, 178047 &, 0544461 \\
Valid N & 161 & & & & \\
\hline
\end{tabular}

For the audit opinion variable, it can be seen in Table 1. frequency of audit opinion, which is $75,4 \%$ or as much as 132 samples having the opinion of qualified opinion. This means that the audit opinion of the districts in the Java Island in the years 2017 and 2018 almost unanimously have a good level of qualification. As much as 24,6 or 43 samples have the predicate of qualified with exceptions, since there are still records that are not according to standard as well as a material issue in the districts in the Java island in the years 2017 and 2018.

\section{B. Results}

The results of the hypothesis testing of this study can be seen in Table 2.

TABLE II: TESTING OF HyPOTHESIS OF DESCRIPTIVE STATISTICS

\begin{tabular}{lcr}
\hline \multicolumn{1}{c}{ Model } & Coefficients $^{\mathrm{a}}$ & \multicolumn{1}{c}{ Sig. } \\
\hline 1 (Constant) & 10.130 &, 000 \\
LT & 20.597 &, 000 \\
LRS & -2.915 &, 004 \\
SAF & 1.372 &, 172 \\
CE & 1.061 &, 290 \\
\hline
\end{tabular}

Bade on the Table 2. The first test results show that the Local Tax has a value of $t_{\text {count }}$ in amount of 20,597 while the

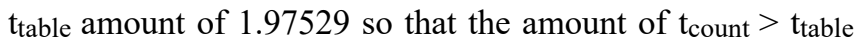
and the significance value of 0.000 is smaller than the level of significance of 0.05 . Therefore $\mathrm{HO}_{\mathrm{O}}$ is rejected and $\mathrm{H}_{\mathrm{A} 1}$ is accepted, so it can be concluded that the Local Tax has a significant effect on Regional Financial Independence. These show that the amount of Local Tax will be followed by the high financial independence of the Regional. Because Local Tax are one of the original county revenue components which provide the highest contribution in, so the Regional can be said independent because it can fund its government activities without relying on assistance that being provided by the center. The results of the study are in line with the research of Novalistia (2016) who found the results that Local Tax affect Regional financial independence.

The second test result shows that the Tax Revenue Sharing has a tcount of -2.915 while the ttable amount of 1.97529 so that the amount of tcount $<$ ttable and the significance value of 0.004 is smaller than the significance level of 0.05 . Therefore $\mathrm{HO} 2$ is rejected and HA2 is accepted, so it can be concluded that the Tax Revenue Sharing has a significant negative effect on Regional Financial Independence. Those show the Tax Revenue Sharing is funds that sourced from the APBN, which are divided into Regionals based on certain percentage figures, and when there's a decreased run into it, the financial independence in 
that Regional increases. Regionals that receive large taxsharing funds do not maximize their original Regional income because they rely on external assistance, one of which is tax-sharing funds, so the more funds that being shared with the Regionals will show the decreased level of Regional financial independence. Then it can be concluded that the tax revenue sharing affects the financial independence of the Regional.

The results of the third test, the Special Allocation Fund has a tcount of 1.372 while the ttable amount of 1.97529 so that the amount of tcount $<$ ttable and the significance value of 0.172 is higher than the significance level of 0.05 . Therefore HO3 is rejected and HA3 is accepted, so it can be concluded that the Special Allocation Fund has no significant effect on Regional Financial Independence. This shows that the results of the study of special allocation funds do not affect the financial independence of the Regional, this is because local governments do not have the authority to manage and use special allocation funds because the use of special allocation funds has been determined by the central government so that Regional governments only carry out what is determined by the central government.

The fourth test result shows that Capital Expenditures has a tcount of 1.061 while the ttable amount of 1.97529 so that the amount of tcount $<$ ttable and a significance value of 0.290 is higher than the significance level of 0.05 . Therefore $\mathrm{HO} 4$ is accepted and HA4 is rejected, so it can be concluded that capital expenditure does not have a significant effect on Regional Financial Independence. The results of capital expenditure research do not affect the financial independence of the Regional, because in order to increase the financial independence of the Regional government, the government is expected to optimize the allocation of capital expenditure. In the regencies / cities in Central Java Province, Regional income is derived from Regional original income and transfer funds, capital expenditure allocations that occur are still uneven or low that in many imbalances in the level of financial independence between Regionals.

\section{CONClusion, Limitations And RECOMMENDATIONS}

Based on the research results above, the partial results of the Regional Tax on Regional Financial Independence with a significant level for the Regional Tax variable of 0,000 smaller than the significance level of 0.05 , this shows that the Regional Tax variable has a significant effect on Regional Financial Independence. The results of the partial research of Tax Profit Sharing to Regional Financial Independence with a significant level for the variable Profit Sharing of 0.004 is smaller than the significant level of 0.05 this shows that the variable Profit Sharing Tax has a significant effect on Regional Financial Independence.

Furthermore, The results of the partial research of the Special Allocation Fund on Regional Financial Independence with a significant level for the Special Allocation Fund variable of 0.172 is higher than the significance level of 0.05 , this indicates that the Special Allocation Fund variable does not significantly influence the Regional Financial Independence. The results of partial research of Capital Expenditure on Regional Financial Independence with a significant level for the Capital Expenditure variable of 0.290 is higher than the significance level of 0.05 , this shows that the variable Capital Expenditure does not significantly influence Regional Financial Independence.

Based on the results of these research, it can be concluded that this research can support the stakeholder theory, which explains that the citizens are the core stakeholders that must be considered by the government. Because the citizen provides resources to the government in the form of Local Tax, and the Regional government, as the holder of power in the government, must prioritize the citizen's interests. The citizen wants to know how the government regulates budget policies that are pro to the citizen, and how much the Regional government's revenue is allocated to the capital expenditure because capital expenditure is very closely related to the infrastructure development and other infrastructure.

This research is also supported by agency theory, which explains that the central government has authority to the Regional government and trusts them by transferring funds to manage their respective Regionals. Tax-sharing funds aim to equalize the Regional financial capacity, but there are often problems with delays in disbursement every quarter, and when it has been paid, arise another problem namely over or underpaid for a Regional. The high amount of special allocation funds provided by the central government to the Regionals raises the agency problems. The Regional government considered detrimental to the central government because in reality the funds managed by the Regional government are not maximized for public services.

\section{REFERENCES}

Ariani, R.K \& Putri, A.G. (2016). 'Pengaruh belanja modal dan dana alokasi umum terhadap tingkat kemadirian keuangan daerah'. Syariah Paper Accounting FEB UMS. ISSN 2460-0784. hlm 364-369.

Darmayasa, N.I dan Bagiada, M.I. (2013). 'Pajak daerah, retribusi daerah, dan bagi hasil pajak sebagai penopang kemandirian keuangan daerah'. Jurnal Bisnis dan Kewirausahaan. Vol.09 No.02. Politeknik Negeri Bali.hlm 121-129.

Darsono, I.L. (2013). 'Pengaruh alokasi belanja modal dan pendapatan asli daerah terhadap kemandirian keuangan pemerintah daerah'. Jurnal Profita. Universitas Negeri Yogyakarta. hlm 11-21.

Dwirandra, A.A.N.B. (2008). 'Efektivitas dan kemandirian keuangan daerah otonom kabupaten/kota di propinsi bali tahun $2002-2006$ '. Jurna Ilmiah. Universitas Udayana. hlm. 01 - 21.

Edogbanya, Adejoh \& Mr. Ja'afaru G. Sule, (2013). 'Revenue generation : it's impact on government developmental effort (a study of selected local council kogi east senatorial district)', Global Journal of Management and Business Research Administration and Management. Volume 13, Issue 4, Version 1.0.

Ernawati (2017).'Pengaruh kinerja pendapatan asli daerah dan belanja modal terhadap kemandirian keuangan daerah'. Jurnal Ilmu dan Riset Akuntansi. ISSN 2460-0585. Vol 6. No. 2. STIESIA Surabya. hlm 532-545.

Ghozali, I. (2016). Aplikasi analisis multivariate dengan program ibm spss 23 : Badan Penerbit Universitas Diponegoro.

Halim, A. (2007). Akuntansi keuangan daerah. Edisi 3. Jakarta: Salemba Empat.

Halim, A. \& Kusufi, M.S. (2012). Akutansi keuangan daerah. Edisi 4, Salemba Empat. Harahap, S. S. (2013). Teori akuntansi. Edisi Revisi 2011. Jakarta: Rajawali Pers.

Imawan, R. dan A. Wahyudin. (2014). 'Analisis kemandirian keuangan daerah'. Accounting Analysis Journal 3(2): 147-155.

Kadafi, M dan Putra, W.W. (2013). 'Kemandirian keuangan daerah (studi kasus pemerintah kota samarinda tahun 2001-2010)'. Prosiding Simposium Nasional Akuntansi Vokasi ke-2. hlm 1-14.

Naganathan, M \& Sivagnanam, J.K. (2000). 'Federal transfer and the tax effort of the states in india'. Indian Economic Journal. Vol. 47 No. 04. University of Madras.hlm 252-281.

Nggilu, F., Sabijono, H. \& Tirayoh, V. (2016). 'Pengaruh pajak daerah dan retribusi daerah terhadap kemandirian keuangan daerah pada pemerintah kabupaten/kota di provinsi gorontalo'. Jurnal Berkala Ilmiah Efisiensi. Vol.16 No.04. Universitas Sam Ratulangi Manado. hlm 623-635. 
Novalistia, L.R. (2016). 'Pengaruh pajak daerah, retribusi daerah, lain-lain pendapatan asli daerah yang sah dan bagi hasil pajak terhadap tingkat kemandirian keuangan daerah pada pemerintahan kabupaten atau kota di provinsi jawa tengah'. Journal Of Accounting. Vol.02 No.02. Universitas Pandanaran Semarang. hlm $1-25$.

Raharjo, E. (2007). Teori agensi dan teori stewardship dalam perspektif akuntansi. Fokus Ekonomi.Vol. 2, No. 1.

Sekaran, U. (2006). Research methods for business, Edisi 4, Jakarta: Salemba Empat.

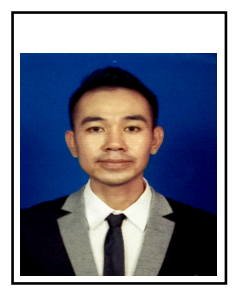

Khoirul Aswar was born in Sumatera Utara, Indonesia. Graduated with a Bachelor's degree in Accountancy from Economics and Business Faculty Janabadra University in 2008. Continued his Master degree in Accountancy study program of the Faculty of Economics, University of Gadjah Mada (FE-UGM), graduated in 2010 and complete. Doctorate degree in Accountancy in Universiti Utara Malaysia. Since 2011 he joined as a lecturer at Economics and Business Faculty Universitas Pembangunan Nasional Veteran Jakarta.

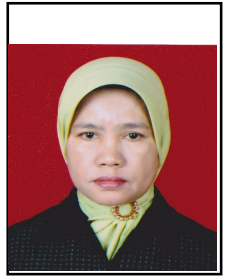

Ermawati was born in Jambi, Indonesia. Graduated with a Bachelor's degree in Accountancy from STIE YAI in 1996. Continued his Master degree in Accountancy study program of the Faculty of Economics, STIE YAI, graduated in 2013 and complete. Since 1996 she joined as a lecturer at Economics and Business Faculty Universitas Pembangunan Nasional Veteran Jakarta. 